\title{
Perbedaan Indeks Plak setelah Pengolesan Ekstrak Daging Buah Naga Merah (Hylocereus costaricensis) dan Larutan Pengungkap
}

(The Difference of Plaque Index after Smeared by Red Dragon Fruit (Hylocereus costaricensis) extract and Disclosing Solution)

Hillary Inggrid Prananta1*, Purwanto ${ }^{2}$, Elyda Akhya Afida Misrohmasari ${ }^{3}$, Niken Probosari ${ }^{4}$, Surartono Dwiatmoko ${ }^{3}$

1 Fakultas Kedokteran Gigi Universitas Jember

2 Bagian Biomedik, Fakultas Kedokteran Gigi Universitas Jember

3 Bagian Ilmu Kesehatan Gigi dan Mulut, Fakultas Kedokteran Gigi Universitas Jember

4 Bagian Pedodonsia, Fakultas Kedokteran Gigi Universitas Jember

\section{Abstrak}

Ekstrak daging buah naga merah mengandung antosianin sebagai pigmen merah yang berpotensi sebagai pewarna alami. Atosianin mengandung polisakarida yang dapat mengikat polisakarida pada plak gigi yang disebut ikatan hidrogen, sehingga plak gigi telah diwarnai dan berpotensi sebagai alternatif pengungkap larutan. Tujuan penelitian ini adalah untuk mengetahui perbedaan indeks plak setelah diolesi ekstrak daging buah naga merah $75 \%$ dan larutan pengungkapan. Metode penelitian ini adalah studi eksperimental klinis dengan rancangan perbandingan kelompok statis. 20 subjek diperiksa indeks plaknya setelah diolesi ekstrak daging buah naga merah 75\%) dan diungkap larutan). Tidak ada perbedaan yang signifikan antar kelompok. Kesimpulan: Ekstrak daging buah naga merah $75 \%$ memiliki kemampuan yang sama dengan pengungkapan larutan untuk pemeriksaan plak gigi.

Kata kunci: Antosianin, Ekstrak Daging Buah Naga Merah Fuchsin Dasar, Indeks Plak Larutan Pengungkap

\section{Abstract}

Red dragon fruit flesh extract contains of anthocyanin as red pigmen that potentially to be a natural dye. Athocyanin contains of polysaccharide that can binding with polysaccharide of dental plaque called hydrogen bonds, so dental plaque has been colored and potentially as alternative of disclosing solution. The purpose of this study was to find out the difference of plaque index after smeared by red dragon fruit flesh extract $75 \%$ and disclosing solution. The method of this study is a clinical experimental study with a static-group comparison design. 20 subjects were examined the plaque index after smeared with red dragon fruit flesh extract 75\%) and disclosing solution). There was no significant difference between groups. Conclusions: Red dragon fruit flesh extract $75 \%$ had similar capability with disclosing solution to examine dental plaque.

Keywords: Anthocyanin, Basic Fuchsin, Disclosing Solution, Plaque Index, Red Dragon Fruit Flesh Extract

Korespondensi (Correspondence) : Hillary Inggrid Prananta. Fakultas Kedokteran Gigi Universitas Jember. Jalan Kalimantan No. 37, Kampus Tegalboto, Jember, Jawa Timur, 68121. Email. ingehip@gmail.com

Penyakit periodontal dan karies terjadi hampir secara menyeluruh di setiap negara baik pada anak-anak maupun dewasal. Etiologi dari penyakit periodontal dan karies adalah akumulasi plak. Plak merupakan lapisan lunak yang membentuk biofilm dan melekat pada permukaan gigi maupun protesa gigi2

Plak tidak berwarna atau transparan sehingga tidak mudah dilihał3. Plak dapat dilihat menggunakan larutan pengungkap (disclosing solution) yang merupakan bahan pendeteksi warna plak ${ }^{4}$. Larutan pengungkap mempunyai kandungan basic fuchsin yang berperan sebagai bahan pewarna ${ }^{5}$. Basic fuchsin merupakan bahan pewarna sintetis yang dapat digunakan untuk mewarnai bakteri, sel, maupun sitoplasma, namun basic fuchsin dapat bersifat toksik dan karsinogen apabila tertelan ${ }^{6,7}$.

Saat ini, gaya hidup kembali ke alam (back to nature) sedang menjadi tren. Masyarakat banyak mengembangkan tumbuhan herbal untuk dimanfaatkan sebagai bahan pengobatan. Pengobatan dengan tumbuhan herbal ini dipilih karena efek samping yang ditimbulkan sangat minimal. Pengobatan dengan tumbuhan herbal juga lebih efektif dibandingkan dengan pengobatan yang mengandung bahanbahan kimia ${ }^{8}$.

Buah naga merah merupakan salah satu contoh tumbuhan herbal yang memiliki banyak manfaat, salah satunya sebagai alternatif pengganti larutan pengungkap. Buah naga merah memiliki kandungan pigmen antosianin yang menyebabkan warna merah yang tidak dimiliki pada buah naga jenis lainnya. Kandungan pigmen antosianin yang terdapat pada daging buah naga merah inilah yang berpotensi sebagai pewarna alami?.

Hakim pada penelitiannya mengenai perbandingan daya tembus pewarna antara larutan pengungkap buatan pabrik dengan ekstrak daging buah naga merah $(H$. 
costaricensis) menyimpulkan bahwa larutan pengungkap memiliki daya tembus warna lebih pendek dibandingkan dengan ekstrak daging buah naga merah $75 \%$ dan memiliki panjang daya tembus yang sama dengan ekstrak daging buah naga 50\%, serta konsentrasi ekstrak daging buah naga merah yang paling optimal sebagai bahan larutan pengungkap adalah konsentrasi $75 \%$.

Menurut Gould dkk., antosianin merupakan pigmen alami yang menyebabkan warna merah yang berlimpah dalam buah dan bunga. Antosianin secara internasional telah diizinkan sebagai zat pewarna makanan karena telah memenuhi persyaratan, yaitu tidak menimbulkan kerusakan pada bahan makanan maupun kemasannya serta tidak beracun bagi tubuh. Sedangkan menurut Husna dkk. (2013), belum ditemukan efek samping konsumsi antosianin karena belum ada laporan toksisitas maupun intoleransi antosianin. Regulasi penggunaan antosianin yang diatur dalam Food and Drugs Administration oleh US dan Uni Eropa menggolongkan antosianin dalam golongan Exempt from Certification Food Additive Color, sehingga penggunaan antosianin tidak mempunyai batas maksimum tertentu selama digunakan secara wajar.

Berdasarkan uraian alasan yang telah dikemukakan tersebut, tujuan penelitian ini adalah untuk meneliti perbedaan indeks plak setelah pengolesan ekstrak daging buah naga merah dan larutan pengungkap

\section{METODE PENELITIAN}

Penelitian ini merupakan jenis penelitian eksperimental klinis dengan rancangan penelitian static-group comparison. Penelitian dilakukan di Laboratorium Tanaman Politeknik Negeri Jember, Laboratorium Teknologi Pangan Politeknik Negeri Jember, dan Klinik Pedodonsia RSGM Fakultas Kedokteran Gigi Universitas Jember pada bulan September November 2018. Subjek terdiri dari 20 orang responden yang menerima dua kali perlakuan, perlakuan pertama untuk eksperimen ekstrak daging buah naga merah, perlakuan kedua untuk larutan pengungkap.

Pertama-tama, dilakukan identifikasi tanaman buah naga merah di Laboratorium Tanaman Politeknik Negeri Jember. Setelah itu, dilanjutkan pembuatan ekstrak daging buah naga merah di Laboratorium Teknologi Pangan Politeknik Negeri Jember. Metode ekstraksi yang digunakan adalah metode maserasi. Daging buah naga merah dihaluskan dengan blender hingga menjadi bubur. Bubur tersebut kemudian diambil sebanyak $440 \mathrm{ml}$ dan dipindahkan ke dalam toples kaca. Setelah itu ditambahkan pelarut etanol $95 \%$ dengan perbandingan bubur : etanol adalah 1 : 10. Perendaman dilakukan selama 24 jam. Hasil perendaman disaring menggunakan kertas saring dan dipekatkan menggunakan fresh dryer selama 36 jam. Setelah itu, diencerkan dengan menambahkan akuades steril $3 \mathrm{ml}$ sehingga diperoleh konsentrasi ekstrak daging buah naga merah $75 \%{ }^{10}$. Sedangkan larutan pengungkap yang digunakan adalah merek Eviplac Solucao by Biodinamica.

Seluruh subjek penelitian terlebih dahulu bersedia mengisi surat persetujuan (informed consent). Sebelum dilakukan perlakuan pertama, subjek diintruksikan untuk tidak menyikat gigi selama 24 jam setelah menyikat gigi di pagi hari dan mencatat seluruh makanan dan minuman (kecuali air putih) yang dikonsumsil'. Setelah 24 jam, subjek diintruksikan berkumur terlebih dahulu untuk menghilangkan sisa-sisa makanan atau debris. Setelah itu, permukaan gigi yang diperiksa dikeringkan dengan semprotan udara, kemudian diolesi ekstrak daging buah naga merah $75 \%$ menggunakan cotton pellet, lalu dilakukan pengukuran indeks plak $^{3}$. Pada perlakuan kedua, subjek kembali diintruksikan untuk melakukan persiapan yang sama yaitu dengan mengonsumsi makanan dan minuman yang sudah dicatat sebelumnya serta tidak menyikat giginya selama 24 jam setelah menyikat gigi di pagi hari. Perlakuan kedua dilakukan pada hari yang berbeda dengan perlakuan pertama. Setelah melakukan persiapan, dilakukan pengolesan menggunakan larutan pengungkap dengan prosedur yang sama dengan perlakuan pertama, kemudian dilakukan pengukuran indeks plak. Semua hasil pengukuran indeks plak dicatat pada lembar pemeriksaan kemudian data yang diperoleh tersebut dilakukan analisis data.

\section{HASIL}

Hasil penelitian yang didapatkan berupa indeks plak 20 orang mahasiswa Fakultas Kedokteran Gigi Universitas Jember angkatan 2018. Rata-rata indeks plak setelah pengolesan ekstrak daging buah naga merah $75 \%$ dan larutan pengungkap dapat dilihat pada Tabel 1.

Tabel 1. Rata-rata indeks plak setelah pengolesan ekstrak daging buah naga merah $75 \%$ dan larutan pengungkap

\begin{tabular}{lcc}
\hline Kelompok Penelitian & $\mathbf{N}$ & Indeks Plak \\
\hline $\begin{array}{l}\text { Ekstrak daging buah } \\
\text { naga merah 75\% }\end{array}$ & 20 & $2,15 \pm 0,43$ \\
$\begin{array}{l}\text { Larutan } \\
\text { pengungkap }\end{array}$ & 20 & $2,21 \pm 0,39$ \\
\hline
\end{tabular}

Hasil dari tabel 1 menunjukkan bahwa rata-rata indeks plak setelah pengolesan larutan pengungkap sedikit lebih tinggi dibandingkan dengan ekstrak daging buah naga merah $75 \%$. Rata-rata indeks plak setelah pengolesan ekstrak daging buah naga merah $75 \%$ adalah 2,1495 sedangkan rata-rata indeks plak setelah pengolesan larutan pengungkap adalah 2,2135 . Selisih dari rata-rata indeks plak pada kedua kelompok tersebut adalah 0,064.

Analisis data dilakukan uji normalitas menggunakan uji Saphiro-wilk. Hasil uji 
menunjukkan data berdistribusi normal $(p>0,05)$. Selanjutnya dilakukan uji statistik parametrik Paired T-test yang menunjukkan hasil data tidak ada beda yang signifikan $(P>0,05)$.

\section{PEMBAHASAN}

Hasil penelitian didapatkan rata-rata indeks plak setelah pengolesan larutan pengungkap sedikit lebih tinggi daripada ekstrak daging buah naga merah $75 \%$. Selisih rata-rata indeks plak pada kelompok ekstrak daging buah naga merah $75 \%$ dan kelompok larutan pengungkap adalah 0,064. Hal ini disebabkan karena perbedaan kandungan yang ada di dalam larutan pengungkap maupun ekstrak daging buah naga merah $75 \%$.

Larutan pengungkap memiliki kandungan basic fuchsin 0,7\%, alkohol 96\%, dan akuades ${ }^{2}$, sedangkan ekstrak daging buah naga merah $75 \%$ memiliki kandungan antosianin $75 \%$, etanol $95 \%$, dan akuades ${ }^{10}$. Basic fuchsin merupakan pewarna sintesis larut air yang biasa digunakan sebagai pewarna bakteri6.13, dimana plak memiliki komposisi terbesar yaitu bakteri14. Antosianin dalam ekstrak buah naga merah $75 \%$ merupakan pigmen alami penghasil warna merah yang melimpah dalam buah dan bunga ${ }^{15}$. Antosianin memliki kestabilan warna merah dalam $\mathrm{pH}$ yang rendah ${ }^{16}$.

Basic fuchsin dalam larutan pengungkap pada dasarnya merupakan senyawa organik yang memiliki kandungan kromofor dan auksokrom. Kromofor digunakan untuk memberikan warna, sedangkan auksokrom digunakan untuk mengikat substrat dan memperkuat intensitas warna. Kromofor memiliki muatan ion-ion positif yang dapat mengikat ion-ion negatif pada bakteri ${ }^{13}$. Oleh sebab itu, larutan pengungkap berbahan dasar basuc fuchsin dengan merek eviplac solucao by Biodinamica yang digunakan dalam penelitian ini memiliki warna lebih pekat dan dapat mewarnai plak lebih lama dibandingkan dengan ekstrak daging buah naga merah $75 \%$.

Antosianin dalam ekstrak daging buah naga merah $75 \%$ adalah bagian dari senyawa flavonoid yang merupakan turunan dari 2phenylbenzopyrylium atau flavylium ${ }^{17}$. Antosianin stabil dalam $\mathrm{pH}$ rendah, sedangkan peningkatan nilai $\mathrm{pH}$ dapat menyebabkan warna antosianin memudar karena kation flavylium yang benwarna merah mengalami hidrasi menjadi karbinol tidak berwarna. Selain itu, penambahan asam sitrat $5 \%$ akan menurunkan $\mathrm{pH}$ antosianin sehingga menjadi lebih stabil16. Hasil penelitian ini menunjukkan bahwa ekstrak daging buah naga merah $75 \%$ menghasilkan warna merah yang berarti kandungan antosianin dalam ekstrak tersebut memiliki pH asam, namun esktrak daging buah naga merah $75 \%$ tidak dapat mewarnai plak lebih lama dan lebih pekat daripada larutan pengungkap berbahan dasar basic fichsin karena tidak ada tambahan asam sitrat 5\% dalam komposisi ekstrak tersebut.

Berdasarkan analisa data, perbedaan hasil tersebut dilakukan uji beda secara statistik. Hasil uji beda secara statistik didapatkan bahwa perbedaan hasil pengukuran indeks plak menggunakan ekstrak daging buah naga merah $75 \%$ dan larutan pengungkap berbahan dasar basic fuchsin tidak signifikan. Hal ini disebabkan karena ekstrak daging buah naga merah $75 \%$ maupun larutan pengungkap memiliki persamaan dalam berikatan dengan plak.

Plak memiliki terdiri atas 2 komponen, yaitu komponen organik dan komponen anorganik. Komponen organik berasal dari bakteri, sedangkan komponen anorganik berasal dari saliva. Di dalam komponen organik tersebut, terdapat kandungan polisakarida yang berperan dalam berikatan dengan bahan larutan pengungkap ${ }^{14}$ maupun antosianin dalam ekstrak daging buah naga merah $75 \%$.

Larutan pengungkap memiliki kandungan polisakarida. Larutan pengungkap dapat mewarnai plak karena adanya suatu ikatan, dimana terjadi perbedaan kepolaran antara komponen larutan pengungkap dan plak, sehingga terjadi interaksi elektrostatis dan ikatan hidrogen antar-polisakarida ${ }^{3}$. Begitu juga dengan antosianin dalam ekstrak buah naga merah $75 \%$. Antosianin terdiri atas 2 komponen, yaitu komponen gula berupa polisakarida dan komponen non-gula berupa antosianidin'18. Polisakarida dalam antosianin dapat berikatan dengan polisakarida dalam plak sehingga dapat mewarnai plak sama seperti larutan pengungkap.

Ikatan hidrogen dapat terjadi karena adanya ikatan antara atom hidrogen yang terikat pada atom elektronegatif19. Polisakarida mempunyai atom hidrogen dan atom elektronegatif yaitu atom $\mathrm{O}$ dan $\mathrm{N}$, sehingga antara polisakarida bakteri plak dengan polisakarida pada antosianin maupun larutan pengungkap dapat berikatan ${ }^{20}$. Sedangkan interaksi elektrostatis dapat terjadi karena adanya gabungan antara gugus karbonil yang memiliki muatan negatif parsial dengan gugus nitrogen yang memiliki muatan postif parsial ${ }^{21}$.

Berdasarkan hasil penelitian yang telah dilakukan, dapat disimpulkan bahwa Ekstrak daging buah naga merah mempunyai kemampuan sebagai bahan pengungkap untuk pemeriksaan indeks plak Saran pada penelitian ini perlu dilakukan penelitian lebih lanjut mengenai tambahan bahan aktif lainnya dalam ekstrak daging buah naga merah sebagai alternatif larutan pengungkap dan perbandingan ekstrak daging buah naga merah dengan pengungkap berbahan dasar tablet.

\section{DAFTAR PUSTAKA}

1. Shahid, M., A. Shahzad, A. Malik, dan A. Sahai. 2013. Recent Trends in 
Biotechnology and Therapeutic Applications of Medicinal Plants. Dordrecht: Springer Science+Business Media.

2. Levi, P. A., R. J. Rudy., Y. N. Jeong., dan D. K. Coleman. 2016. Non-Surgical Control of Periodontal Diseases: A Comprehensive Handbook. Heidelberg: Springer.

3. Datta, D., S. G. R. Kumar, M. B. A. Narayanan, A. L. Selvamary, dan A. Sujatha. 2017. Disclosing solutions used in dentistry. World Journal of Pharmaceutical Research. 6(6): 16481656.

4. Robinson, D. S. dan D. L. Bird. 2013. Essentials of Dental Assisting. Edisi Kelima. China: Elsevier Saunders.

5. Febriyanti, I. D., I. D. Liana, R. Indriyani, dan S. Christiono. 2018. The effect of roselle (Hibiscus sabdariffa L.) petals extract as alternative disclosing solution for dental plaque identification. Dentino Jurnal Kedokteran Gigi. 3(2): 108-115.

6. Sabnis, R. W. 2010. Handbook of Biological Dyes and Stains. Canada: John Wiley and Sons, Inc.

7. Santa Cruz. 2012. Material Safety Data Sheet Basic Fuchsin. California: Santa Cruz Biotechnology, Inc.

8. Redaksi AgroMedia. 2008. Buku Pintar Tanaman Obat: 431 Jenis Tanaman Penggempur Aneka Penyakit. Jakarta: PT Agromedia Pustaka.

9. Sartika, D. 2016. Ekstraksi dan Stabilitas Antosianin dalam Kulit Buah Naga Merah dan Daging Buah Naga Merah sebagai Pewarna Alami (Hylocereous polyrhizus). Skripsi. Bandung: Program Studi Teknologi Pangan Fakultas Teknik Universitas Pasundan.

10. Hakim, A. 2018. Perbandingan Daya Tembus Pewarna antara Disclosing Solution (Larutan Pengungkap) Buatan Pabrik dengan Ekstrak Daging Buah Naga Merah (Hylocereus costaricensis). Skripsi. Jember: Fakultas Kedokteran Gigi Universitas Jember.

11. Mangiri, B. S., S. Yani, dan S. Anitasari. 2018. Sari buah naga super merah (hylocereus costaricensis) sebagai pewarna alami plak gigi. Jurnal Material Kedokteran Gigi. 7(1): 28-34.

12. Biodinamica. 2011. Eviplac Solucao Evidenciadora de Placa Bacteriana. Brazil: Biodinamica Quimica E Farmaceutica LTDA.

13. Sumbali, G. dan R. S. Mehrotra. 2009. Principle of Microbiology. New Delhi: Tata McGraw Hill Education Private Limited.

14. Newman, M. G., H. H. Takei, dan F. A. Carranza. 2012. Carranza's Clinical Periodontology. Edisi Kesebelas. United States of America: W. B. Saunders Company.

15. Gould, K., K. Davies, dan C. Winefield. 2009. Anthocyanins: Biosynthesis, Functions, and Applications. Dordrecht: Springer Science+Business Media.

16. Ingrath, W., W. A. Nugroho, dan R. Yulianingsih. 2015. Ekstraksi pigmen antosianin dari kulit buah naga merah (Hylocereus costaricensis) sebagai pewarna alami makanan dengan menggunakan microwave. Jurnal Bioproses Komoditas Tropis. 3(3): 1-8.

17. Mazza, G. 2018. Anthocyanins in Fruits, Vegetables, and Grains. Boca Raton: CRC Press Taylor \& Francis Group.

18. Wallace, T. C. dan M. M. Giusti. 2014. Anthocyanins in Health and Disease. Boca Raton: CRC Press Taylor \& Francis Group.

19. Prananto, Y. P. 2013. Ikatan Hidrogen: Persembahan dari Unsur paling Kecil di Alam.

http://prananto.lecture.ub.ac.id/files/20 13/12/lkatan-Hidrogen 1.pdf. [Diakses pada 6 Desember 2018].

20. Sumardjo, D. 2009. Pengantar Kimia: BukU Panduan Kuliah Mahasiswa Kedokteran dan Program Strata I Fakultas Bioeksakta. Jakarta: EGC.

21. Marks, D. B., A. D. Marks, dan C. M. Smith. 2000. Biokimia Kedokteran Dasar: Sebuah Pendekatan Klinis. Jakarta: EGC 